\title{
The Cholesterol Concentration in Mammals' Milk - Is It a Real Content?
}

\author{
Anna Malwina Kamelska* \\ Clinic of Rehabilitation, Poland \\ *Corresponding author: Anna Malwina Kamelska, Clinic of Rehabilitation,, Poland

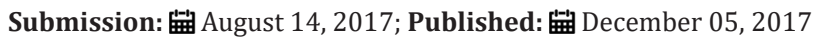

Abbreviations: ChC: Cholesterol Concentration; GC: Gas Chromatography; HPLC: High Performance Liquid Chromatography; DAD: Diode Array Detector; FTIR-ATR: Fourier Transformed Infrared Spectroscopy

\section{Mini Review \\ Recently the use of colostrum and mature milk derived from various mammals in feeding both infants and adults has been gaining more and more popularity. The reason for this is mainly its hypocholesterolemic action, better bioavailability, therapeutic properties (used in the gastro-intestinal disorders) and no allergies after consumption.}

The composition of milk plays a crucial role for the newborn mammals' health. And one of its main components is cholesterol. There are many factors affecting the cholesterol concentration (ChC) in milk e.g. breed, species and the age of animals, milk yield, as well as the following lactation, lactation phase, animal's health status and diet. Moreover, even as minor detail as time of the day may have an impact on the ChC $[1,2]$.

Animal's feeding (also maternal nutrition during pregnancy and/or lactation in humans) is highly important in the case of fetal programming and epigenetic regulation. Moreover, it is related to the adequate development of the fetus, infant and future adult [3]. Some research shows that feeding infants with high-cholesterol breast milk influences the metabolism of this steroid and prevents the occurrence of hypercholesterolemia in later life. High cholesterol exposure in infancy might lead to cholesterol decrease and permanently stimulate its catabolism in adulthood [4].

Furthermore, the differences in the $\mathrm{ChC}$ in the same sample may be associated with the use of different analytical methods. Some of the procedures have got several shortcomings. Routinely used methods are mainly based on the extraction of fat as the initial step, which is both time- and labor-consuming. Moreover, multiple reagents are required. In order to avoid tedious pre-treatment and extraction procedures some authors extracted cholesterol from milk and dairy products using direct saponification. Its duration's influence on cholesterol concentration was shown in previous study [5]. This paper addresses the hypothesis that the
ChC obtained using various analytical methods does not do justice to the real content of this sterol in the sample. This is due to the problems and shortcomings of recently used analytical methods and the knowledge gap in the regulatory processes.

Cholesterol concentration has been determined mostly using colorimetric methods [6,7], gas chromatography (GC) followed by thin layer chromatography separation [8] or GC alone [9], high performance liquid chromatography (HPLC) coupled to diode array detector (DAD) [10] and attenuated total reflectance Fourier transformed infrared spectroscopy (FTIR-ATR) [11]. The comparison of cholesterol concentration (ChC) in mammals' milk using different analytical methods has been shown in Table 1. Specific period of lactation (colostrum/mature milk) has been indicated [12-38].

Cholesterol concentration in mature human milk is lower than in cow's milk and higher than in infant formulas. Moreover, $\mathrm{ChC}$ in infant formulas $\left(0.93-5.45 \mathrm{mg} / 100 \mathrm{~cm}^{3}\right)$ [39] is relatively low as compared to breast milk. Moreover, the content of this sterol in human milk is about $20 \%$ higher than that of bovine and caprine milk [40]. However, the comparison of the cholesterol concentration in mammals' milk is way more difficult because different authors use different analytical methods. Furthermore, different methods are associated with different units, which complicate the proper cholesterol concentration comparison. Moreover, according to some authors, pasteurized milk was characterized by reduced ChC compared to mature milk and colostrum [19]. The concentration of this compound in the colostrum of mammals is generally higher than in mature milk or is at a constant level. What is more, no scientific studies determined the concentration of cholesterol in human colostrum, which could become a future research aim. Also, the comparison of the cholesterol concentration in various mammals using the same analytical method is needed. 
Table 1: The comparison of the cholesterol concentration $(\mathrm{ChC})$ in different mammals' milk and the analytical methods used.

\begin{tabular}{|c|c|c|c|c|}
\hline Milk Samples & & ChC [mg dL-1] & Method & Reference \\
\hline \multirow{5}{*}{ Cow (Bos taurus) } & Collostrum & 9,49 & Precht [12] & Precht [12] \\
\hline & mature (pasteurized) & 11,78 & IDF Standard & Pikul [13] \\
\hline & mature (pasteurized) & $2,37-3,06$ & Cerutti et al. [14] & Cerutti et al. [14] \\
\hline & mature & $16,25-18,63$ & Šterna et al. [15] & Šterna \& Jemeljanovs [15] \\
\hline & mature & 14,94 & Fletouris et al. [16] & Talpur et al. [17] \\
\hline \multirow{2}{*}{ Mare (Equus cabalus) } & collostrum & 19,33 & Bao-Shyung et al. [18] & Pikul [19] \\
\hline & mature & 7,23 & Bao-Shyung et al. [18] & Pikul [19] \\
\hline \multirow{6}{*}{ Goat (Capra hircus) } & collostrum & 9,43 & Direct saponification & Zaharia et al. [20] \\
\hline & mature (pasteurized) & 8,51 & IDF Standard & Pikul [13] \\
\hline & mature & 16,23 (summer), 11,30 (autumn) & $\begin{array}{l}\text { Balice Animal Husbandry } \\
\text { Institute }\end{array}$ & Wolanciuk [21] \\
\hline & mature & 9,8 & Ulberth et al. [22] & Mayer et al. [23] \\
\hline & mature & $15,68-19,10$ & $\begin{array}{c}\text { Fletouris et al. [16], Searcy } \\
\text { et al. [24] }\end{array}$ & Strzałkowska et al. [25] \\
\hline & mature & 14 & $\begin{array}{l}\text { Folch et al. [26], Rudel et } \\
\text { al. [27] }\end{array}$ & Park [28] \\
\hline Sheep (Ovis aries) & mature & 11,6 & Ulberth et al. [22] & Mayer et al. [23] \\
\hline \multirow{2}{*}{ Buffalo (Bubalus bubalis) } & collostrum & $\begin{array}{c}\text { 12,93-9,02 (summer-autumn), } \\
12,68-7,88 \text { (winter-spring) }\end{array}$ & Borkovcová et al. [29] & Coroian et al. [30] \\
\hline & mature & 8 & Kovacs et al. [31] & Zotos et al. [32] \\
\hline Yak (Bos mutus) & mature & 14,25 & Fletouris et al. [16] & He et al. [33] \\
\hline \multirow{5}{*}{ Human (Homo sapiens) } & mature & 12 & Park et al. [34] & Scopesi et al. [35] \\
\hline & mature & 10,57 & Paradkar \& Iruyuida [36] & Kamelska et al. [11] \\
\hline & mature & 9,88 & IDF Standard & Kamelska et al. [11] \\
\hline & mature & 7,06 & IDF Standard & Kamelska et al. [37] \\
\hline & mature & 5,38 & Kamelska, Bryl 2012 [38] & Kamelska, Bryl [38] \\
\hline
\end{tabular}

\section{Acknowledgement}

The author would like to thank Rafał Sadowski (MA) for proofreading the article.

\section{References}

1. Faye B, Bengoumi M, Al-Masaud A, Konuspayeva G (2015) Comparative milk and serum cholesterol content in dairy cow and camel. J King Saud Univ Sci 27(2): 168-175.

2. Kamelska AM, Pietrzak-FR, Bryl K (2012) Variation of the cholesterol content in breast milk during 10 days collection at early stages of lactation. Acta Biochim Pol 59(2): 243-247.

3. Netting MJ, Middleton PF, Makrides M (2014) Does maternal diet during pregnancy and lactation affect outcomes in offspring? A systematic review of food-based approaches. Nutrition 30(11-12): 1225-1241.

4. Owen CG, Whincup PH, Kaye SJ, Martin RM, Davey SG, et al. (2008) Does initial breastfeeding lead to lower blood cholesterol in adult life? A quantitative review of the evidence. Am J Clin Nutr 88(2): 305-314.
5. Kamelska AM, Jarmołowska B, Bryl K (2015) A simplified enzymatic method for total cholesterol determination in milk. Int Dairy J 50: 50-57.

6. Alvarez SA, Garcia LG, Barberà R, Lagarda MJ (2015) Determination of cholesterol in human milk: an alternative to chromatographic methods. Nutr Hosp 32(4): 1535-1540.

7. Bachman KC, Lin JH, Wilcox CJ (1976) Sensitive colorimetric determination of cholesterol in dairy products. J Assoc Off Anal Chem 59(5): 1146-1149.

8. Clark RM, Fey MB, Jensen RG, Hill DW (1983) Desmosterol in human milk. Lipids 18(3): 264-266.

9. Kallio MJT, Siimes MA, Perheentupa J, Salmenperä L, Miettinen TA (1989) Cholesterol and its precursors in human milk during prolonged exclusive breast feeding. Am J Clin Nutr 50(4): 782-785.

10. Ramalho HM, Casal S, Oliveria MBPP (2011) Total cholesterol and desmosterol contents in raw, UHT, infant formula powder and human milks determined by a new fast micro-HPLC method. Food Anal Methods 4(3): 424-430. 
11. Kamelska AM, Pietrzak FR, Bryl K (2013) Determination of cholesterol concentration in human milk samples using attenuated total reflectance Fourier transform infrared spectroscopy. J Appl Spectrosc 80(1): 148152.

12. Precht D (2001) Cholesterol content in European bovine milk fats. Nahrung 45(1): 2-8.

13. Pikul J, Rudzińska M, Teichert J, Lasik A, Danków R, et al. (2013) Cholesterol oxidation during storage of UHT-treated bovine and caprine milk. Int Dairy J 30(1): 29-32.

14. Cerutti G, Machado MA, Ribolzi L (1993) The distribution of cholestero in milk and milk products. Latte 18(11): 1102-1108.

15. Sterna V, Jemeljanovs A (2003) Comparison of fatty acids and cholestero content in the milk of Latvian cows. Vet Zootec 22(44): 95-98.

16. Fletouris DJ, Botsoglou NA, Psomas IE, Mantis AI (1998) Rapid determination of cholesterol in milk and milk products by direct saponification and capillary gas chromatography. J Dairy Sci 81(11): 2833-2840.

17. Talpur FN, Bhanger MI, Khuhawar MY (2006) Comparison of fatty acids and cholesterol content in the milk of Pakistani cow breeds. J Food Compos Anal 19(6-7): 698-703.

18. Bao-SH, Jin-TW, Youk-MC (2003) A simplified method for the quantification of total cholesterol in lipids using gas chromatography. J Food Compos Anal 16: 169-178.

19. Pikul J, Wójtowski J (2008) Fat and cholesterol content and fatty acid composition of mares' colostrum and milk during five lactation months. Livest Sci 113(2-3): 285-290.

20. Zaharia N, Salamon R, Pascal C, Salamon S, Zaharia R (2011) Changes in fatty acid composition and cholesterol content of goat colostrums. Biotech Anim Husbandry 27(3): 1201-1208.

21. Wolanciuk A, Barłowska J, Pastuszka R, Topyła B (2013) The basic chemical composition and selected parameters of goat milk from summer and autumn-winter feeding period. Scientific Annals of the Polish Society of Animal Science 9(2): 63-70.

22. Ulberth F, Reich H (1992) Gas chromatographic determination of cholesterol in processed foods. Food Chem 43: 387-391.

23. Mayer HK, Fiechter G (2012) Physical and chemical characteristics of sheep and goat milk in Austria. Int Dairy J 24: 57-63.

24. Searcy RL, Berquist LM (1960) A new color reaction for the quantitation of serum cholesterol. Clin Chim Acta 5: 192-199.

25. Strzałkowska N, Bagnicka E, Jóźwik A, Krzyżewski J (2006) Concentration of total cholesterol in milk of Polish White improved goats during whole lactation. Archiv Tierzucht, Dummenstorf 49: 166-173.

26. Folch J, Lees M, Stanley GHS (1957) A simple method for the isolation and purification of total lipids from animal tissues. J Biol Chem 226(1): 497-500.

27. Rudel LL, Morris MD (1973) Determination of cholesterol using o-phthaladehyde. J Lipid Res 14(3): 364-366.

28. Park YW (2000) Comparison of mineral and cholesterol composition of different commercial goat milk products manufactured in USA. Small Ruminant Res 37(1-2): 115-124.

29. Borkovcová I, Janoušková E, Dračková M, Janštová B, Vorlová L (2009) Determination of sterols in dairy products and vegetable fats by HPLC and GC methods. Czech J Food Sci 27: S217-S219.

30. Coroian A, Erler S, Matea CT, Miresan V, Răducu C, et al. (2013) Seasonal changes of buffalo colostrum: physicochemical parameters, fatty acids and cholesterol variation. Chem Cent J 7(1): 40.

31. Kovacs MIP, Andreson WE, Ackman RG (1979) A simple method for determination of cholesterol and some plant sterols in fishery-based food products. J Food Sci 44(5): 1299-1305.

32. Zotos A, Bampidis VA (2014) Milk fat quality of Greek Buffalo (Bubalus bubalis). J Food Compos Anal 33: 181-186.

33. He S, Ma Y, Wang J, Li Q, Yang X, et al. (2011) Milk fat chemical composition of yak breeds in China. J Food Compos Anal 24(2): 223-230.

34. Park SW, Addis PB (1986) Identification and quantitative estimation of oxidized cholesterol derivatives in heated tallow. J Agric Food Chem 34: 653-659.

35. Scopesi F, Zunin P, Mazzella M, Testa M, Boggia R, et al. (2002) 7-ketocholesterol in human and adapted milk formulas. Clin Nutr 21(5): 379 384.

36. Paradkar MM, Irudayaraj JI (2002) Determination of cholesterol in dairy products by infrared techniques: 2. FT-IR method. Int J Dairy Tech 55(3): 133-138.

37. Kamelska AM, Pietrzak-FR, Bryl K (2012) Variation of the cholesterol content in breast milk during 10 days collection at early stages of lactation. Acta Biochim Pol 59(2): 243-248.

38. Kamelska AM, Bryl K (2012) The assessment of cholesterol content in human milk collected during day and night ("ocena zawartości cholesterolu w mleku kobiecym pobieranym w trakcie dnia oraz w nocy"). Humanistic essays XII 3(29): 25-35.

39. Kamelska AM, Pietrzak-FR, Bryl K (2011) The cholesterol content as an infant food quality determinant, ("zawartość cholesterolu jako determinanta jakości żywności dla niemowląt”). Scientific Papers of University of Economy in Poznan 196: 38-45.

40. Yao Y, Zhao G, Xiang J, Zou X, Jin Q et al. (2016) Lipid composition and structural characteristics of bovine, caprine and human milk fat globules. Int Dairy J 56: 64-73. 